tivity affirms is a universe in which there is no absolute space-time order; in which every event is exhausted in the contradictory descriptions of observers in different systems of reference; in which systems of reference are ultimate without being absolute, and relative without being externally conditioned; in which every system is self- sufficing and contains its own norm, a norm which remains constant by changing as the system changes. In such a universe, are mathematics and physical science possible? The relativist claims that they are capable of infinitely greater precision and consistency than they could ever attain while obstructed by the old concept.

\title{
Bibliography of Relativity.
}

A BIBLIOGRAPHY of all books, pamphlets, A papers, articles, and other publications on the subject of relativity has been prepared by Dr. $\mathrm{H}$. Forster Morley, director of the International Catalogue of Scientific Literature. The list includes nearly 650 titles, arranged in chronological order from 1886 to the end of last year. It would occupy about thirty columns of NATURE, and, much as we should like to print it in full, limitations of space render this impossible. We have, therefore, extracted from Dr. Morley's bibliography the titles of published books and pamphlets upon relativity and related subjects, and also the references to articles, notes, or other contributions which have appeared in the pages of Nature. The complete bibliography is so valuable that we trust it will be published in full either by a scientific society or in a leading work on relativity. Dr. R. W. Lawson has kindly added the titles of a number of German works.

\section{BoOKS AND PAMPhLETS.}

Lorentz, H. A. La théorie electromagnétique de Maxwell et son application aux corps mouvants. Leyden (E. J. Brill) I892.

Lorentz, H. A. Versuch einer Theorie der elektrischen und optischen Erscheinungen in bewegten Körpern. Leyden (E. J. Brill) I895.

Lobatschewsky, N. I. Zwei geometrische Abhandlungen. Uebersetzt von F. Engel. Leipzig 1898 .

Woods, Frederick Shenstone. Forms of NonEuclidean Space. The Boston Colloquium Lectures. New York Igo5 $\left(3^{x-74}\right)$.

Michelson, A. A. Light Waves and their Uses. Chicago 1907 .

Lecornu, Léon. La mécaniçue. Paris (Flammarion) rgog.

Lorentz, H. A. The Theory of Electrons. Lectures delivered in Columbia University I906; Leipzig (Teubner) rgog $(\mathrm{iv}+332)$.

Minkowski, Hermann. Zwei Abhandlungen über die Grundgleichungen der Elektrodynamik. Mit einem Einführungswort von Otto Blumenthal. Leipzig und Berlin (B. G. Teubner) I9Io (82).

Planck, Max. Allgemeines Dynamik-Prinzip der Relativität. [In: Planck, Acht Vorlesungen über theoretische Physik.] Leipzig (S. Hirzel) rgro (I IO-27).

Poincaré, Henri. La mécanique nouvelle. I $I_{n}$ : Mathematische Vorlesungen an der Universität Göttingen. IV.] Leipzig und Berlin (B. G. Teubner) I9 Io [1909] $\left(49-5^{8}\right)$.

Winkelmann, A. Handbuch der Physik. 3 Aufl. Optik. Leipzig (J. A. Barth).

Bonola, R. Ueber die Parallelentheorie und über die nichteuklidischen Geometrien. Leipzig u. Berlin (Teubner) 19II $(246-363)$.

Laue, Max. Das Relativitätsprinzip. (Die Wissenschaft H. 38.) Braunschweig (F. Vieweg \& S.) I9I I $(\mathrm{x}+208)$.

$$
\text { No. } 2677 \text {, VOL. I06] }
$$

Robb, Alfred A. Optical Geometry of Motion. Cambridge (W. Heffer) IgII.

Sommerville, D. M. $\}$. Bibliography of NonEuclidean Geometry, including the Theory of Parallels, the Foundations of Geometry and Space of $n$ Dimensions. London (Harrison) IgII (xii+404).

Woods, Frederick Shenstone. Non-Euclidean Geometry. London I9II.

Bonola, Roberto. Non-Euclidean Geometry. Translated by $\mathrm{H}$. S. Carslaw. Chicago (Open Court Pub. Co.) I912 (xii+268).

Borgman, Ivan Ivanovitch. [New Ideas in Physics. An Aperiodic Scientific Series. No. 3: The Principle of Relativity (Russian).] St. Petersburg I9I2 (172-76). With index of literature.

Carlebach, Joseph. Die Geschichte des Trägheitssatzes im Lichte des Relativitätsprinzips. (Wiss. Beilage zum Jahresbericht der Margaretenschule. Ostern I912.) Berlin (Wiedmann) 1912 (24).

Ehrenfest, Paul. Zur Krise der Lichtäther-Hypo these. Rede. Berlin (J. Springer) I9I3 (23); Leyden (Eduard IJdo) IgI2 (24).

Henschke, Erich. Ueber eine Form des Prinzips der kleinsten Wirkung in der Elektrodynamik des Relativprinzips. Diss. Berlin. Leipzig (J. A. Barth) IgI2 (88).

Huntington, Edward V. A New Approach to the Theory of Relativity. Festschrift Heinrich Weber. Leipzig I912 (147-69).

Schottky, Walter. Zur relativtheoretischen Energetik und Dynamik. I. II. Diss. Berlin. Weida i. Th. (Thomas \& Hubert) I9I2 (iii 95 ).

Einstein, A., und Grossmann, M. Entwurf einer verallgemeinerten Relativitätstheorie und einer Theorie der Gravitation. Leipzig (Teubner) r913 (38).

Planck, Max. Das Prinzip der Erhaltung der Energie. Leipzig (Teubner) I9I3 (xvi+278). Third edition.

Poincaré, Henri. Science and Method; also contained in The Foundations of Science. New York (Science Press) I913.

Carmichael, Robert Daniel. The Theory of Relativity. (Mathematical Monographs, No. I2.) New York (J. Wiley); London (Chapman \& Hall) I9I3 (74). Carus, P. The Principle of Relativity in the Light of the Philosophy of Science. Chicago and London (Open Court Pub. Co.) I9I3 (I05).

Gandillot, M. Note sur une illusion de relativité. Paris (Gauthier-Villars) I9I3 (88).

Laue, Max. Das Relativitätsprinzip. 2. verm. Aufl. Braunschweig (F. Vieweg \& S.) I9I3 (xii+272).

Lorentz, Hendrik Antoon. Het relativiteits-beginsel. [Le principe de la relativité. Trois conférences faites dans la fondation Teyler.] Haarlem (de Erven Lossjes) [1913] (6o).

Lorentz, Hendrik Antoon, Einstein, Albert, und Minkowski, Hermann. Das Relativitätsprinzip. Eine Sammlung von Abhandlungen mit Anmerkung von 
Arnold Sommerfeld und Vorwort von Otto Blumenthal. Leipzig und Berlin (Teubner) r9I3 (iv +89 ). (Fortschritte der mathematischen Wissenschaften in Monographien, Heft 2.)

Silberstein, L. Vectorial Mechanics. London (Macmillan) r9I3 (viii + rg7).

Weinstein, Max B. Die Physik der bewegten Materie und die Relativitätstheorie. Leipzig (J. A. Barth) I9I3 (xii+424).

Conway, A. W. Relativity. Edin. Math. Tracts, No. 3. London 1913 (43); London (G. Bell and Sons) I9I5 (43).

Weinstein, Max B. Kräfte und Spannungen: Das Gravitations- und Strahlungsfeld. Heft 8. Braunschweig (Sammlung Vieweg) rgi4 (vi +64$)$.

Abraham, Max. Theorie der Elektrizität. 2. Aufl. Bd. II. Elelitromagnetische Theorie der Strahlung. Leipzig u. Berlin (B. G. Teubner). Third edition I9I4.

Cnnningham, E. The Principle of Relativity. Cambridge (Univ. Press) r9i4 (xiv +221 ).

Gilbert, Leo. Das Relativitätsprinzip; die jüngste Modenarrheit der Wissenschaft. Band I. Brackwede $\dot{i}$. W. (Breitenbach) I9I4 (124).

Robb, A. A. A Theory of Time and Space. Cambridge (Univ. Press) I9I4 (vi+373)

Silberstein, L. The Theory of Relativity. London (Macmillan) rgr4 (viii+295).

Cunningham, E. Relativity and the Electron Theory. London (Longmans) $19{ }^{1} 5$ (vii+96).

Einstein, A. Die Grundlagen der allgemeinen Relativitätstheorie. Leipzig (J. A. Barth) IgI6.

Cohn, E. Physikalisches über Raum und Zeit. (Abh. u. Vortr. aus d. Geb. d. Math. Naturwiss. u. Tech., Heft 2.) Leipzig (Teubner) 1916.

Droste, Johannes. Het zwaartekrachtsveld van een of meer lichamen volgens de theorie van Einstein [The Gravitation Field of One or More Bodies according to Einstein's Theory]. Leyden (Brill) I9I6 (72).

Lémeray, E. M. Actualités scientifiques. Le principe de relativité. Paris (Gauthier-Villars) I9I6 (I55).

Tolman, R. C. The Theory of the Relativity of Motion. Berkeley (Univ. of California Press) I9r7 (ix+225).

Polak, W. J. Bezwaren tegen de opvattingen der Relativisten [Objections aux conceptions des relativistes]. Deventer (A. E. Kluwer) 1918 (63).

Verhoeck, Paulus Martinus. De vierdimensionale wereld der relativistische Natuurkunde [Le monde à quatre dimensions de la physique relativiste]. Vereeniging van Ingenieurs in Zuid-Limburg, April I9I8 (56).

Brose, H. L. The Theory of Relativity. Oxford (B. H. Blackwell) 19i9 (32).

Weyl, H. Raum, Zeit, Materie. Berlin (Springer) 1918. Fourth edition I920.

Brill, A. Das Relativitätsprinzip : eine Einführung in die Theorie. Leipzig und Berlin (B. G. Teubner) I912 (iv+29); 2. Aufl. I9I4 (iv+34); 4. Aufl. I920.

Carr, H. Wildon. The General Principle of Relativity: In its Philosophical and Historical Aspect. London (Macmillan) ig20 $(x+165)$.

Eddington, A. S. Report on the Relativity Theory of Gravitation. London (Physical Society of London). Second edition 1920 .

Eddington, A. S. Space, Time, and Gravitation : An Outline of the General Relativity Theory. Cambridge (Univ. Press) 1920 (vii+218).

Einstein, A. Ueber die spezielle und die allgemeine Relativitätstheorie (Gemeinverständlich). Heft $3^{8}$. NO. 2677 , VOL. IO6]
Braunschweig (Sammlung Vieweg) I920 (iv +83 ). Fifth edition [first edition 19r6].

Einstein, Albert. Relativity: The Special and the General Theory. A popular exposition. Authorised translation by Robert W. Lawson. London (Methuen) $1920(x i i+138)$.

Einstein, A. Aether und Relativitätstheorie. Rede gehalten am 5 Mai Ig20 an der Reichs-Universität zu Leiden. Berlin (J. Springer) 1920 ( 15$)$.

Freundlich, E. Die Grundlagen der Einsteinschen Gravitationstheorie, mit einem Vorwort von A. Einstein. Berlin (Springer) I920 $(v i+96)$. Fourth edition.

Freundlich, Erwin. The Foundations of Einstein's Theory of Gravitation. Authorised English translation by Henry L. Brose. Preface by Albert Einstein. Introduction by H. H. Turner. Cambridge (Univ. Press) I920 (xvi+6r).

Harrow, Benjamin. From Newton to Einstein : Changing Conceptions of the Universe. London (Constable) r920 (95).

Kopff, U. Die Einsteinsche Relativitätstheorie. Leipzig (Greszner und Schramm) I920 (24).

Reichenbach, H. Relativitätstheorie und Erkenntnis a priori. Berlin (Springer) 1920 ( $v+r i o)$.

Sampson, R. A. On Gravitation and Relativity: Being the Halley Lecture delivered on June 12, 1920. Oxford (Clarendon Press) (24).

Slosson, Edwin E. Easy Lessons in Einstein. A Discussion of the more Intelligible Features of the Theory of Relativity. With a Bibliography. London (Routledge); New York (Harcourt, Brace, and Howe) rg20 (vii +128 ).

Schlick, M. Raum und Zeit in der gegenwärtigen Physik. Berlin (Springer) r9zo (vi+9o). Third edition.

Schlick, Moritz. Space and Time in Contemporary Physics: An Introduction to the Theory of Relativity and Gravitation. Rendered into English by Henry L. Brose. With an Introduction by F. A. Lindemann. Oxford (Clarendon Press) 1920 (xi +89$)$. .

Schmidt, H. Das Weltbild der Relativitätstheorie. Hamburg (Paul Hartung). Second (enlarged) edition 1920 (viii+ I39).

Einstein, A., and Minkowski, H. The Principle of Relativity. Original Papers Translated into English by M. N. Saha and S. N. Bose. Calcutta (University) r920 (xxiii + I86).

Frank, Ph. Relativitätstheorie. Leipzig (Teubner) I920 (320).

Riemann, B. Ueber die Hypothesen, welche der Geometrie zu Grunde liegen. Neu herausgegeben und erläutert von Prof. H. Weyl. Berlin (Springer) I920. Schlesinger, L. Raum, Zeit und Relativitätstheorie. (Abh. u. Vortr aus d. Geb. d. Math. Naturwiss. u. Tech., Heft 5.) Leipzig. (Teubner) rg2o.

Bloch, W. Einführung in die Relativitätstheorie. Leipzig (Teubner) I920. Second edition.

Angersbach, A. Das Relativitätsprinzip. (Math.phys. Bibl. 39.) Leipzig (Teubner) 1920.

Lorentz, H. A. Das Relativitätsprinzip; Drei Vorlesungen gehalt. n Teylers Stiftung zu Haarlem. Bearbeitet von W. H. Keesom. Leipzig (Teubner) I920.

Born, Max. Die Relativitätstheorie Einsteins und ihre physikalischen Grundlagen. (Naturwissenschaftliche Monographien und Lehrbücher, Band 3.) Berlin (Springer) I920.

Laue, M. v. Die Relativitätstheorie. Vol. i.: Das Relativitätsprinzip der Lorentztransformation. Braunschweig (Vieweg) I920. Fourth edition. Vol. ii. will be published early in $192 \mathrm{r}$. 
witte, Hans. Raum und Zeit im Lichte der neueren Physik. Heft i7. Braunschweig (Sammlung Vieweg) Ig20 (88). Second edition.

Minkowski, H. Gesammelte Abhandlungen. Unter Mitwirkung von A. Speiser und $H$. Weyl; heraus. gegeben von D. Hilbert. Leipzig (Teubner) 1920. 2 vols.

Born, Max. Der Aufbau der Materie. Berlin (Springer) I920.

Lenard, P. Uber Relativitätsprinzip, Aether, Gravitation. Leipzig (Hirzel) I920. Third edition.

Schneider, Ilse. Das Raum-Zeit-Problem bei Kant und Einstein. Berlin (Springer) I92I.

Lämmel, Rudolf. Die Grundlagen der Relativitätstheorie. Berlin (Springer) I92 I.

\section{"NATURE."}

Cunningham, E. The Principle of Relativity. Discussion of Rep. Brit. Assoc. of I9II. 87 rgII (500).

Cunningham, E. The Principle of Relativity. 93 x9I4 (378-79, 408-Io, 454).

(454).

Robb, A. A. The Principle of Relativity. 93 1914

Cunningham, E. Fizeau's Experiment and the

Principle of Relativity. 94 I914 (197-98, 226-27, 281).

Larmor, Joseph. Fizeau's Experiment and the

Principle of Relativity. 94 I9I4 (28r).

Shaw, P. E. Gravitation and Temperature. 97 $1916(400-1)$.

Cunningham, E., and Eddington, A. S. Gravitation.

Rep. Brit. Assoc. of Igr6. 98 I9I6 (120).

Eddington, A. S. Gravitation and the Principle of

Relativity. 98 1916 (328-3I).

Barton, E. H. Thermodynamics and Gravitation.

99 г 9 I7 $(44-45)$.

Larmor, J. Radiation-pressure, Astrophysical Retardation, and Relativity. 99 I9I7 (404).

Lodge, O. Gravitation and Thermodynamics.

99 I9I7 (104-5).

Shaw, P. E. Gravitation and Thermodynamics. 99 I 9 I7 $(84-85$, I65).

Todd, G. W. Thermodynamics and Gravitation:

A Suggestion. 99 I9I7 $\left(5^{-6}\right.$, I04 $\left.^{-5}\right)$.

Lodge, O., and Eddington, A. S. Relativity and Gravitation. 100 rgI7 (33).

Eddington, A. S. Gravitation and the Principle of Relativity. [Royal Institution Lecture.] 101 IgI8 $\left(5^{-17}, 34-36\right)$.- Relativity and Gravitation. 101 1918 (126).

Jeffreys, Harold. The Motion of the Perihelion of Mercury. 101 IgI8 (IO3, I45).

O'Farrell, H. H. Relativity and Gravitation. 101 1918 (I26).

Anon., Total Solar Eclipse, June 8, I918. 162 1918 $(89-90)$.

Crommelin, A. C. D. Solar Eclipse, May 29, I9I9. 102 I9I9 $(444-46)$.

Anderson, Alexander. The Displacement of Light Rays Passing near the Sun. 104 rgr9 (354).-Deflection of Light during Solar Eclipse. 104 I919 (354, $393-94,436)$.

Crommelin, A. C. D. Results of the Total Solar Eclipse of May 29 and the Relativity Theory. 104 I919 $(280-8 \mathrm{I})$. - The Deflection of Light during a Solar Eclipse. 104 I9I9 (372-73).-The Einstein Theory and Spectral Displacement. 104 I920 (532).--The Theory of Relativity: Report of Discussion at the Royal Society's Meeting on February 5, r920. 104 1920 $(631-32)$.

No. 2677 , VOL. I06]
Cunningham, E. Einstein's Relativity Theory of Gravitation. I.-III. 104 I919 (354-56, 374-76, 394-95).-Einstein's Theory and a Map Analogue. 104 I920 (437).

Dines, W. H. The Deflection of Light during a Solar Eclipse. 104 I9 I9 (393).

Duffield, W. G. Relativity and the Displacement of Fraunhofer Lines. 104 I $200(659-60)$.

Eddington, A. S. The Deflection of Light during a Solar Eclipse. 104 I9I9 (372).-- [Account of Observations made at Principe during Solar Eclipse. Brit. Assoc. I9I9.] 104 Ig20 (454).-The Predicted Shift of Fraunhofer Lines. 104 I920 (598-99).

Joly, J. Relativity and Radio-activity. 1041920 $(468)$.

Larmor, J. Gravitation and Light. 104 1919 (412, $530)$.

Lawson, Robert W. Displacement of Spectral Lines. 104 r920 $(565)$.

Lodge, Oliver J. Gravitation and Light. $104 \quad 1919$ $(334,354,372)$.

Moulton, H. Fletcher. The Einstein Theory and Spectral Displacement. $1041920(532)$.

Page, Leigh. Gravitational Deflection of Highspeed Particles. 104 1920 (692-93).

Rice, J. The Predicted Shift of Fraunhofer Lines. 104 r920 (598-99).

Richardson, L. F. The Deflection of Light during a Solar Eclipse. 104 I919 (393-94).

Rutherford, E., and Compton, A. H. Radio-activity and Gravitation. 104 I9I9 (4I2).

Crommelin, A. C. D. Deflection of Light during a Solar Eclipse. 105 I920 (8).-Einstein's Deflection of Light. 105 I920 $(23-24)$.

Cunningham, E. Review of Freundlich's "Foundations of Einstein's Theory of Gravitation." 1651920 $\left(35^{0}-5^{1}\right)$.

Eddington, A. S. Gravitational Deflection of Highspeed Particles. 105 r920 (37).

Jeffreys, Harold. Gravitational Shift of Spectral Lines. 105 I920 $(37-38)$

McAulay, Alexander. Relativity and Hyperbolic Space. 105 r920 (808).

Orange, J. A. Deflection of Light during a Solar Eclipse. 105 I920 (8).

Page, Leigh. Gravitational Deflection of Highspeed Particles. 105 I920 (233).

Poole, Horace H. The FitzGerald-Lorentz Contraction Theory. 105 I920 (200).

Sampson, R. A. Relativity and Reality. 105 I920 (708).

Evershed. [Abstract of Paper on Shift of Fraunhofer Lines Observed at Kodaikanal Observatory.] 106 I920 (357)-The Einstein Spectral Shift. 106 I92 I (705). [Abstract of Bulletin No. 64 of Kodaikanal Observatory.]

Haldane, Viscount. Philosophy of Relativity [Review of $\mathrm{H}$. Wildon Carr: The General Principle of Relativity]. 106 I920 (43I-32).

Lodge, Oliver. Popular Relativity and the Velocity of Light. 106 I920 $\left(3^{2} 5^{-26}\right)$ - - - CAbstract of Paper on Velocity of Light read before British Association in 1920.] 106 1920 (358).--Einstein's Shift of Spectral Lines. 106 r920 (373).

Partington, J. R. Relativity. 106 I920 ( $\mathrm{II}_{3}-\mathrm{I}_{4}$ ).

Synge, E. H. The Space-Time Hypothesis before Minkowski. 106 192 I (693). 